\title{
Effect of Packaging Materials and Form Son Storability of Summer Groundnut (Arachis hypogaea L.) Cv. G2-52
}

\author{
N. Vijayalakshmi* and T.A. Malabasari \\ Department of Seed Science and Technology, College of Agriculture, UAS, \\ Dharwad-580005, Karnataka, India \\ *Corresponding author
}

\section{A B S T R A C T}

\section{Keywords \\ Seedling vigour index, Mobilization efficiency, \\ 100 seed weight, PICS bag \\ Article Info \\ Accepted: \\ 07 October 2018 \\ Available Online: \\ 10 November 2018}

An experiment was conducted at Seed Quality Research Laboratory of National Seed Project, University of Agricultural Sciences, Dharwad during 2016-2017 to evaluate the effect of packaging materials and forms on storability of groundnut $\mathrm{Cv}$. G2-52.The groundnut is stored both in the form of pods and kernels, and they were stored in four different packaging materials like PICS (Perdue improved crop storage) bag, HDPE (High density polythene bag) bag, polythene bag (700 gauge), and gunny bag. Among the interactions $\mathrm{T}_{1}$ (pod stored in PICS bag) showed maximum seed quality parameters like germination (81.17 \%), seedling vigour index (1675), 100 seed weight (36.19 g), mobilization efficiency $(8.81 \%)$. Whereas the lowest germination $(55.17)$, seedling vigour index (815), 100 seed weight $(31.15 \mathrm{~g})$, mobilization efficiency $(7.40 \%)$ were recorded in $\mathrm{T}_{8}$ (kernel stored in gunny bag) at the eight month of storage period.

\section{Introduction}

Groundnut (Arachis hypogaea L.), is "king of oil seed crops", is believed to be native of Brazil (South America). Groundnut is also called as wonder nut and poor men's cashew nut.

Storing seeds after harvest till the next planting season without impairing the quality is of prime importance for successful seed production. Groundnut being an oil seed crop groundnut seed has short life and looses its viability quickly under ambient conditions. Ageing in groundnut seed leads to increased lipid peroxidation, decreased activities of several free radical and peroxide scavenging enzymes (Rao et al., 2006). Groundnut seeds are more sensitive to storage conditions like high temperature; high seed moisture content and light exposure. The problem of loss of seed viability is more serious in groundnut harvested in the summer season and about 50 per cent viability could be lost within 4 to 5 months of storage in such produce (Nautiyal $e t$ al., 1990; Nautiyal and Ravindra, 1996). Seeds with high oil content, appear to loose their germination and vigour in a short time despite the precaution taken during harvesting and drying (Nautiyal et al., 1990).

In storage the viability and vigour of seeds not only vary from genera to genera and variety to variety but also regulated by many physico- 
chemical factors like moisture content, atmospheric relative humidity, temperature, initial seed quality, physical and chemical composition of seed, gaseous exchange, storage structures and packaging materials etc., (Doijode, 1988). As the seed is hygroscopic in nature, seed quality is affected by variation in moisture content, relative humidity, temperature etc. To combat these factors, it's better to store the seeds in moisture vapour proof containers like polythene bags, gunny bag lined with polythene with or without desiccating agent to maintain the quality of seed for longer period by reducing moisture content to a desired level.

However, storability of summer seed produce is an additional constraint to maintain the seedling establishment in the field. Such problem is generally due to high temperature prevailing during drying period and subsequent storage during kharif season where in, high humidity causes rapid seed deterioration. Therefore, several attempts have been made by several workers in many crops to develop methods for maintaining the viability and vigour of seeds for longer period during storage. It is known fact that the choice of suitable form of seed (Both pod and kernel), containers selected for storing the seeds and storage environment exert a positive effect on the viability and vigour of the seeds in storage. In this direction, presently groundnut seeds are stored in the form of pod which involves bulk handling and huge area required for storage. Hence, storage of kernel can be thought off. But, as such kernel cannot not be stored without proper drying and storing them in suitable packaging materials.

\section{Materials and Methods}

The storage experiment was conducted in the Seed Quality Research Laboratory of National Seed Project, Seed unit, University of
Agricultural Sciences, Dharwad on "Effect of Packaging Materials and Forms on Storability of Summer Groundnut (Arachis hypogaea L.) Cv. G2-52" The experiment was conducted during the period of July 2016 to March, 2017. Seeds of groundnut Cv. G2-52 were obtained from the Seed Unit, UAS, Dharwad which were harvested from 2016 summer season. Both pod and kernel forms were used for storage studies. The pods were hand shelled and used for experimental purpose.

Four packaging materials were used for the experiment like PICS ( $\mathrm{P}_{1}$-Perdue improved crop storage bag), HDPE bag $\left(\mathrm{P}_{2}\right)$, polythene bag700 gauge $\left(\mathrm{P}_{3}\right)$ and gunny bag $\left(\mathrm{P}_{4}\right)$.

\section{Description of PICS (Perdue Improved Crop Storage) bag used in this experiment}

The PICS bag is a triple bagging hermatic technology consisted of two liners made out of high-density polyethylene (HDPE) and an outer woven layer of polypropylene that provides protection during handling. Together, these bags create a low-oxygen environment that reduces development of stored-grain insects (Murdock et al., 2012). The mean data obtained from the experiment was statistically analysed and subjected to the Analysis of variance by adopting appropriate statistical methods as outlined by Panse and Sukhatme (1967). The critical differences were calculated at one per cent level of significance. The percentage data of germination were transformed into arc sine root transformation before analysis.

\section{Germination percentage}

The standard germination counts were taken on $5^{\text {th }}$ day and $10^{\text {th }}$ day as first and final count. Total germination percentage was calculated on the basis of number of normal seedlings obtained in the final count expressed in percentage (Anon., 2011). 
Number of normal seedling Obtained on final count Germination $(\%)=$----------- x 100 Number of seeds put for germination

\section{Seedling Vigour index}

Seedling vigour index was calculated by adopting the formula as suggested by AbdulBaki and Anderson (1973).

Vigour index $=$ Germination $(\%) \mathrm{X}$ [Root length $(\mathrm{cm})+$ Shoot length $(\mathrm{cm})]$

\section{0 seed weight}

Individual samples of hundred kernels each were drawn at random and weighed. The mean weight of the three samples were recorded and expressed in grams (g) as per ISTA rules (Anon., 2011).

\section{Mobilization efficiency}

Mobilization efficiency is defined as mobilization and utilization of food reserves during seed germination. Seeds with higher food reserves are known to produce vigorous seedling owing to better capacity to supply food materials to seedlings. It also depends upon species, size of seed and food reserves. It is calculated by the following formula (Shrivastava and Sareen, 1974) and it is expressed in percentage.

Dry weight of seedlings (mg) Mobilization efficiency $(\%)=$---------- x 100

Dry weight of seeds (mg)

\section{Results and Discussion}

\section{Germination (\%)}

The results of germination percentage as influenced by packaging materials and forms (pod and kernel) during storage are presented in Table 1. With the advancement of storage period, the mean germination declined from 93.00 per cent at the initial stage to 55.17 per cent at the end of storage period irrespective of packaging materials, forms and their interactions. Germination percentage due to packaging materials differed significantly in all the months of storage. The seeds stored in PICS bag recorded maximum germination of 80.50 per cent after eight months of storage period followed by seeds stored in polythene bag $(78.25 \%)$. The lowest germination of 58.33 per cent was noticed in seeds stored in gunny bag after eight months of storage.

Among the forms, the germination percentage due to forms differed significantly in all the months of storage. The seeds stored in pod form recorded maximum germination of 72.25 per cent after eight months of storage period whereas, the lowest germination of 69.04 per cent was noticed in the seeds stored in in the form of kernel after eight months of storage. However, the interaction of packaging materials and forms showed non-significant difference throughout the storage period.

Groundnut seeds stored in PICS bag storage acted as a hermatic storage which works on the principle of creating airtight conditions in which oxygen level was lowered due to insect, fungal and seed respiration, which maintained the seed quality parameters. While the seeds stored in gunny bag recorded lower values that may be attributed to fluctuation of moisture content, leading to a faster deterioration in seeds stored in gunny bag. These findings are in agreement with Sudini et al., (2014) in groundnut, Patra et al., (1998) in groundnut.

\section{Seedling vigour index}

The mean seedling vigour index decreased at initial stage from 2250 to 815 after eight months of storage irrespective of packaging material and forms. 
Table.1 Effect of packaging materials and forms on germination (\%) and seedling vigour index of groundnut variety G2-52

\begin{tabular}{|c|c|c|c|c|c|c|c|c|c|c|c|}
\hline \multirow{3}{*}{\multicolumn{2}{|c|}{ Treatments }} & \multicolumn{5}{|c|}{ Germination (\%) } & \multicolumn{5}{|c|}{ Seedling vigour index } \\
\hline & & \multicolumn{5}{|c|}{ Months after storage } & \multicolumn{5}{|c|}{ Months after storage } \\
\hline & & $\begin{array}{l}\text { Initial } \\
\text { month }\end{array}$ & $\begin{array}{c}2^{\text {nd }} \\
\text { month }\end{array}$ & $\begin{array}{c}4^{\text {th }} \\
\text { month }\end{array}$ & $\begin{array}{c}6^{\text {th }} \\
\text { month }\end{array}$ & $\begin{array}{c}8^{\text {th }} \\
\text { month }\end{array}$ & $\begin{array}{l}\text { Initial } \\
\text { month }\end{array}$ & $\begin{array}{c}2^{\text {nd }} \\
\text { month }\end{array}$ & $\begin{array}{c}4^{\text {th }} \\
\text { month }\end{array}$ & $\begin{array}{c}6^{\text {th }} \\
\text { month }\end{array}$ & $\begin{array}{c}8^{\text {th }} \\
\text { month }\end{array}$ \\
\hline \multirow{7}{*}{$\begin{array}{l}\text { Packaging } \\
\text { materials } \\
(P)\end{array}$} & $\left(P_{l}\right)$ & $\begin{array}{c}93.00 \\
(74.68) *\end{array}$ & $\begin{array}{c}91.17 \\
(72.74)\end{array}$ & $\begin{array}{c}87.42 \\
(69.33)\end{array}$ & $\begin{array}{c}83.67 \\
(66.28)\end{array}$ & $\begin{array}{c}80.50 \\
(63.87)\end{array}$ & 2250 & 2096 & 1937 & 1785 & 1635 \\
\hline & $\left(P_{2}\right)$ & $\begin{array}{c}93.00 \\
(74.68)\end{array}$ & $\begin{array}{c}84.92 \\
(67.21)\end{array}$ & $\begin{array}{c}75.42 \\
(60.32)\end{array}$ & $\begin{array}{c}71.92 \\
(58.03)\end{array}$ & $\begin{array}{c}66.50 \\
(54.67)\end{array}$ & 2250 & 1808 & 1526 & 1339 & 1160 \\
\hline & $\left(P_{3}\right)$ & $\begin{array}{c}93.00 \\
(74.68)\end{array}$ & $\begin{array}{c}90.50 \\
(72.10)\end{array}$ & $\begin{array}{c}86.08 \\
(68.18)\end{array}$ & $\begin{array}{c}81.58 \\
(64.64)\end{array}$ & $\begin{array}{c}78.25 \\
(62.25)\end{array}$ & 2250 & 2029 & 1839 & 1669 & 1514 \\
\hline & $\left(P_{4}\right)$ & $\begin{array}{c}93.00 \\
(74.68)\end{array}$ & $\begin{array}{c}83.67 \\
(66.19)\end{array}$ & $\begin{array}{c}68.00 \\
(55.61)\end{array}$ & $\begin{array}{c}64.25 \\
(53.31)\end{array}$ & $\begin{array}{c}58.33 \\
(49.81)\end{array}$ & 2250 & 1672 & 1252 & 1098 & 907 \\
\hline & Mean & $\begin{array}{c}93.00 \\
(74.68)\end{array}$ & $\begin{array}{c}87.56 \\
(69.56)\end{array}$ & $\begin{array}{c}79.23 \\
(63.36)\end{array}$ & $\begin{array}{c}75.35 \\
(60.56)\end{array}$ & $\begin{array}{c}70.90 \\
(57.65)\end{array}$ & 2250 & 1901 & 1638 & 1473 & 1304 \\
\hline & S.Em. \pm & 0.32 & 0.38 & 0.57 & 0.54 & 0.45 & 16.92 & 18.07 & 18.46 & 20.88 & 18.27 \\
\hline & C.D. $(0.01)$ & NS & 1.03 & 1.55 & 1.48 & 1.23 & NS & 49.40 & 50.44 & 57.06 & 49.93 \\
\hline \multirow{5}{*}{$\begin{array}{l}\text { Forms } \\
\qquad(F)\end{array}$} & $\left(F_{l}\right)$ & $\begin{array}{c}93.00 \\
(74.68) *\end{array}$ & $\begin{array}{c}88.33 \\
(70.18)\end{array}$ & $\begin{array}{c}81.04 \\
(64.53)\end{array}$ & $\begin{array}{c}77.00 \\
(61.62)\end{array}$ & $\begin{array}{c}72.75 \\
(58.80)\end{array}$ & 2250 & 1934 & 1695 & 1525 & 1363 \\
\hline & $\left(F_{2}\right)$ & $\begin{array}{c}93.00 \\
(74.68)\end{array}$ & $\begin{array}{c}86.79 \\
(68.93)\end{array}$ & $\begin{array}{l}77.42 \\
(62.19)\end{array}$ & $\begin{array}{c}73.71 \\
(59.51)\end{array}$ & $\begin{array}{c}69.04 \\
(56.50)\end{array}$ & 2250 & 1868 & 1582 & 1421 & 1245 \\
\hline & Mean & $\begin{array}{c}93.00 \\
(74.68)\end{array}$ & $\begin{array}{c}87.56 \\
(69.56)\end{array}$ & $\begin{array}{c}79.23 \\
(63.36)\end{array}$ & $\begin{array}{c}75.35 \\
(60.56)\end{array}$ & $\begin{array}{c}70.90 \\
(57.65)\end{array}$ & 2250 & 1901 & 1638 & 1473 & 1304 \\
\hline & S.Em. \pm & 0.23 & 0.05 & 0.08 & 0.08 & 0.06 & 2.44 & 2.61 & 2.66 & 3.01 & 2.64 \\
\hline & C.D. $(0.01)$ & NS & 0.149 & 0.224 & 0.213 & 0.178 & NS & 7.13 & 7.28 & 8.23 & 7.20 \\
\hline \multirow[t]{11}{*}{$\begin{array}{l}\text { Interaction } \\
(P X F)\end{array}$} & $T_{l^{-}} P_{1} F_{1}$ & $\begin{array}{c}93.00 \\
(74.68)^{*}\end{array}$ & $\begin{array}{c}91.33 \\
(72.90)\end{array}$ & $\begin{array}{c}87.67 \\
(69.53)\end{array}$ & $\begin{array}{c}84.17 \\
(66.69)\end{array}$ & $\begin{array}{c}81.17 \\
(64.37)\end{array}$ & 2250 & 2106 & 1960 & 1810 & 1675 \\
\hline & $\mathbf{T}_{2}-\mathbf{P}_{1} \mathbf{F}_{2}$ & $\begin{array}{c}93.00 \\
(74.68)\end{array}$ & $\begin{array}{c}91.00 \\
(72.58)\end{array}$ & $\begin{array}{c}87.17 \\
(69.14)\end{array}$ & $\begin{array}{c}83.17 \\
(65.87)\end{array}$ & $\begin{array}{c}79.83 \\
(63.37)\end{array}$ & 2250 & 2087 & 1914 & 1759 & 1594 \\
\hline & $\mathbf{T}_{3}-\mathbf{P}_{2} \mathbf{F}_{1}$ & $\begin{array}{c}93.00 \\
(74.68)\end{array}$ & $\begin{array}{c}86.50 \\
(68.47)\end{array}$ & $\begin{array}{c}77.67 \\
(61.82)\end{array}$ & $\begin{array}{c}74.50 \\
(59.68)\end{array}$ & $\begin{array}{c}69.50 \\
(56.50)\end{array}$ & 2250 & 1858 & 1592 & 1407 & 1230 \\
\hline & $\mathbf{T}_{\mathbf{4}}-\mathbf{P}_{\mathbf{2}} \mathbf{F}_{\mathbf{2}}$ & $\begin{array}{c}93.00 \\
(74.68)\end{array}$ & $\begin{array}{c}83.33 \\
(65.96)\end{array}$ & $\begin{array}{c}73.17 \\
(58.82)\end{array}$ & $\begin{array}{c}69.33 \\
(56.38)\end{array}$ & $\begin{array}{c}63.50 \\
(52.83)\end{array}$ & 2250 & 1759 & 1459 & 1271 & 1090 \\
\hline & $\mathbf{T}_{5}-\mathbf{P}_{3} \mathbf{F}_{1}$ & $\begin{array}{c}93.00 \\
(74.68)\end{array}$ & $\begin{array}{c}90.67 \\
(72.27)\end{array}$ & $\begin{array}{c}86.33 \\
(68.40)\end{array}$ & $\begin{array}{c}82.00 \\
(64.95)\end{array}$ & $\begin{array}{c}78.83 \\
(62.66)\end{array}$ & 2250 & 2046 & 1848 & 1692 & 1546 \\
\hline & $T_{6}-P_{3} F_{2}$ & $\begin{array}{c}93.00 \\
(74.68)\end{array}$ & $\begin{array}{c}90.33 \\
(71.92)\end{array}$ & $\begin{array}{c}85.83 \\
(67.96)\end{array}$ & $\begin{array}{c}81.17 \\
(64.32)\end{array}$ & $\begin{array}{c}77.67 \\
(61.84)\end{array}$ & 2250 & 2012 & 1830 & 1647 & 1482 \\
\hline & $\mathbf{T}_{7}-\mathbf{P}_{4} \mathbf{F}_{1}$ & $\begin{array}{c}93.0 \\
(74.68)\end{array}$ & $\begin{array}{c}84.83 \\
(67.09)\end{array}$ & $\begin{array}{c}72.50 \\
(58.38)\end{array}$ & $\begin{array}{c}67.33 \\
(55.16)\end{array}$ & $\begin{array}{c}61.50 \\
(51.65)\end{array}$ & 2250 & 1727 & 1378 & 1189 & 999 \\
\hline & $\mathbf{T}_{8}-\mathbf{P}_{4} \mathbf{F}_{2}$ & $\begin{array}{c}93.0 \\
(74.68)\end{array}$ & $\begin{array}{c}82.50 \\
(65.28)\end{array}$ & $\begin{array}{c}63.50 \\
(52.85)\end{array}$ & $\begin{array}{c}61.17 \\
(51.46)\end{array}$ & $\begin{array}{c}55.17 \\
(47.97)\end{array}$ & 2250 & 1616 & 1125 & 1008 & 815 \\
\hline & Mean & $\begin{array}{c}93.00 \\
(\mathbf{7 4 . 6 8})\end{array}$ & $\begin{array}{c}87.56 \\
(69.56)\end{array}$ & $\begin{array}{c}79.23 \\
(63.36)\end{array}$ & $\begin{array}{c}75.35 \\
(60.56)\end{array}$ & $\begin{array}{c}70.90 \\
(57.65)\end{array}$ & 2250 & 1901 & 1638 & 1473 & 1304 \\
\hline & S.Em. \pm & 0.39 & 0.22 & 0.33 & 0.31 & 0.26 & 9.8 & 10.43 & 10.7 & 12.1 & 10.55 \\
\hline & C.D. $(0.01)$ & NS & NS & NS & NS & NS & NS & NS & NS & NS & NS \\
\hline
\end{tabular}

Figures in parenthesis indicates arcsine transformed values.

Packaging materials (P): $\mathrm{P}_{1^{-}}$PICS Bag, $\mathrm{P}_{2^{-}}$HDPE Bag, $\mathrm{P}_{3^{-}}$Polythene bag, $\mathrm{P}_{4^{-}}$Gunny bag.

Seed forms $(\mathrm{F})$ : $\mathrm{F}_{1}-\mathrm{Pod}, \mathrm{F}_{2}$-Kernel.

NS: Non-significant. 
Table.2 Effect of packaging materials and forms on 100 seed weight $(\mathrm{g})$ and mobilization efficiency $(\%)$ of groundnut variety G2-52

\begin{tabular}{|c|c|c|c|c|c|c|c|c|c|c|c|}
\hline \multirow{3}{*}{\multicolumn{2}{|c|}{ Treatments }} & \multicolumn{5}{|c|}{100 seed weight $(\mathrm{g})$} & \multicolumn{5}{|c|}{ Mobilization efficiency (\%) } \\
\hline & & \multicolumn{5}{|c|}{ Months after storage } & \multicolumn{5}{|c|}{ Months after storage } \\
\hline & & $\begin{array}{l}\text { Initial } \\
\text { month }\end{array}$ & $\begin{array}{c}2^{\text {nd }} \\
\text { month }\end{array}$ & $\begin{array}{c}4^{\text {th }} \\
\text { month }\end{array}$ & $\begin{array}{c}6^{\text {th }} \\
\text { month }\end{array}$ & $\begin{array}{c}8^{\text {th }} \\
\text { month }\end{array}$ & $\begin{array}{l}\text { Initial } \\
\text { month }\end{array}$ & $\begin{array}{c}2^{\text {nd }} \\
\text { month }\end{array}$ & $\begin{array}{c}4^{\text {th }} \\
\text { month }\end{array}$ & $\begin{array}{c}6^{\text {th }} \\
\text { month }\end{array}$ & $\begin{array}{c}8^{\text {th }} \\
\text { month }\end{array}$ \\
\hline \multirow{7}{*}{$\begin{array}{l}\text { Packaging } \\
\text { materials } \\
(P)\end{array}$} & $\left(P_{l}\right)$ & 38.20 & 37.68 & 37.18 & 36.86 & 36.08 & 9.66 & 9.34 & 9.18 & 8.97 & 8.77 \\
\hline & $\left(P_{2}\right)$ & 38.20 & 36.97 & 36.10 & 35.68 & 34.56 & 9.66 & 8.63 & 8.43 & 8.25 & 8.05 \\
\hline & $\left(P_{3}\right)$ & 38.20 & 37.49 & 36.82 & 36.51 & 35.62 & 9.66 & 9.20 & 8.98 & 8.79 & 8.60 \\
\hline & $\left(P_{4}\right)$ & 38.20 & 35.39 & 34.33 & 33.22 & 31.73 & 9.66 & 8.11 & 7.94 & 7.74 & 7.51 \\
\hline & Mean & 38.20 & 36.88 & 36.11 & 35.57 & 34.50 & 9.66 & 8.82 & 8.63 & 8.43 & 8.23 \\
\hline & S.Em. \pm & 0.10 & 0.46 & 0.45 & 0.44 & 0.43 & 0.08 & 0.07 & 0.07 & 0.07 & 0.06 \\
\hline & C.D. (0.01) & NS & 1.25 & 1.22 & 1.21 & 1.17 & NS & 0.29 & 0.29 & 0.27 & 0.24 \\
\hline \multirow{5}{*}{$\begin{array}{l}\text { Forms } \\
\qquad(F)\end{array}$} & $\left(F_{l}\right)$ & 38.20 & 37.19 & 36.51 & 36.17 & 35.08 & 9.66 & 9.42 & 9.18 & 8.97 & 8.77 \\
\hline & $\left(F_{2}\right)$ & 38.20 & 36.57 & 35.70 & 34.96 & 33.91 & 9.66 & 8.83 & 8.43 & 8.25 & 8.05 \\
\hline & Mean & 38.20 & 36.88 & 36.11 & 35.57 & $\mathbf{3 4 . 5 0}$ & 9.66 & 9.12 & 8.80 & 8.61 & 8.41 \\
\hline & S.Em. \pm & 0.07 & 0.07 & 0.06 & 0.06 & 0.06 & 0.05 & 0.04 & 0.05 & 0.05 & 0.04 \\
\hline & C.D. (0.01) & NS & NS & $N S$ & 0.174 & 0.169 & NS & 0.15 & 0.20 & 0.19 & 0.17 \\
\hline \multirow{11}{*}{$\begin{array}{c}\text { Interaction } \\
\quad(P X F)\end{array}$} & $T_{1^{-}} P_{1} F_{1}$ & 38.20 & 37.75 & 37.26 & 36.95 & 36.19 & 9.66 & 9.40 & 9.23 & 9.01 & 8.81 \\
\hline & $\mathbf{T}_{2}-\mathbf{P}_{1} \mathbf{F}_{2}$ & 38.20 & 37.62 & 37.10 & 36.77 & 35.97 & 9.66 & 9.28 & 9.13 & 8.93 & 8.73 \\
\hline & $\mathbf{T}_{3^{-}}-\mathbf{P}_{2} \mathbf{F}_{1}$ & 38.20 & 37.08 & 36.21 & 35.87 & 34.79 & 9.66 & 8.73 & 8.53 & 8.34 & 8.14 \\
\hline & $\mathbf{T}_{\mathbf{4}}-\mathbf{P}_{2} \mathbf{F}_{2}$ & 38.20 & 36.86 & 35.98 & 35.50 & 34.34 & 9.66 & 8.53 & 8.33 & 8.15 & 7.95 \\
\hline & $\mathbf{T}_{5^{-}} \mathbf{P}_{3} \mathbf{F}_{1}$ & 38.20 & 37.56 & 36.91 & 36.61 & 35.78 & 9.66 & 9.25 & 9.04 & 8.84 & 8.66 \\
\hline & $T_{6}-P_{3} F_{2}$ & 38.20 & 37.43 & 36.73 & 36.41 & 35.47 & 9.66 & 9.15 & 8.92 & 8.74 & 8.54 \\
\hline & $\mathbf{T}_{7}-\mathbf{P}_{4} \mathbf{F}_{1}$ & 38.2 & 36.38 & 35.66 & 35.28 & 33.59 & 9.70 & 8.20 & 8.00 & 7.80 & 7.60 \\
\hline & $\mathbf{T}_{8}-\mathbf{P}_{4} \mathbf{F}_{2}$ & 38.2 & 34.40 & 33.01 & 31.15 & 29.87 & 9.70 & 8.00 & 7.80 & 7.60 & 7.40 \\
\hline & Mean & 38.20 & 36.88 & 36.11 & 35.57 & 34.50 & 9.66 & 8.82 & 8.63 & 8.43 & 8.23 \\
\hline & S.Em. \pm & 0.13 & 0.25 & 0.27 & 0.25 & 0.25 & 0.09 & 0.09 & 0.09 & 0.09 & 0.08 \\
\hline & C.D. $(0.01)$ & NS & NS & NS & 0.70 & 0.68 & NS & NS & NS & NS & NS \\
\hline
\end{tabular}

Packaging materials $(\mathrm{P})$ : $\mathrm{P}_{1^{-}}$- PICS Bag, $\mathrm{P}_{2^{-}}$HDPE Bag, $\mathrm{P}_{3^{-}}$Polythene bag, $\mathrm{P}_{4^{-}}$Gunny bag.

Seed forms (F): $F_{1}$-Pod, $F_{2}$-Kernel.

NS: Non significant

Among the packaging materials significantly higher seedling vigour index of 1635 was recorded in the seeds stored in PICS bag as compared to the seeds stored in gunny bag which recorded the lowest (907) seedling vigour index at the end of storage period. The forms have also differed significantly on seedling vigour index during all the months of storage. Seedling vigour index was significantly maximum (1363) in the pod form as compared to kernel form of storage which recorded lowest (1245) seedling vigour index. Interaction of packaging materials and forms showed non-significant difference throughout the storage period are presented in
Table 1. Vigour index decreased with the advancement of storage period which was mainly due to increase in storage period the germination percentage and seedling length decreased, decrease in germination percentage is positively correlated with decrease in seedling vigour index. These results are in conformity with the findings of Basavegowda and Ravikumar (2001) in groundnut.

\section{0 seed weight $(g)$}

The results of hundred seed weight as influenced by packaging materials and forms (pod and kernel) during storage are presented 
in Table 2. With the advancement of storage period, the mean seed weight was declined from $38.20 \mathrm{~g}$ at the initial stage to $29.87 \mathrm{~g}$ at the end of storage period irrespective of packaging materials, forms and their interactions. Seed weight due to packaging materials differed significantly in all the months of storage. The seeds stored in PICS bag recorded maximum 100 seed weight of $36.08 \mathrm{~g}$ after eight months of storage period followed by the seeds stored in polythene bag $35.62 \mathrm{~g}$. The lowest 100 seed weight of 31.73 $\mathrm{g}$ was noticed in the seeds stored in gunny bag after eight months of storage.

Among the forms, the germination percentage due to forms differed significantly from the sixth month of storage period. The seeds stored in pod form recorded maximum seed weight of $35.08 \mathrm{~g}$ at eighth months of storage period. Whereas, the lowest (34.96 g) seed weight was noticed in the seeds stored in in the form of kernel after eight months of storage.

Among the interaction of packaging materials and forms showed non-significant difference up to fourth month of storage period, from the sixth month interaction of these two factors showed significant difference throughout storage period. At the eighth month of storage period the highest $(36.19 \mathrm{~g})$ seed weight was noticed in $\mathrm{T}_{1}$, followed by $\mathrm{T}_{2}(35.97 \mathrm{~g})$. Whereas, the lowest (29.87 g) seed weight was noticed in $\mathrm{T}_{8}$ at the end of storage period are presented in Table 2. It was mainly due to the seeds stored in PICS bag acted as a hermatic storage container creating airtight condition with low level of oxygen.

Whereas, insect and pathogen activity was less, the seeds stored in gunny bag lead to attack of insects and pathogen which led to damage of seeds which in turn reduced the seed weight. These results are in conformity with Sudini et al., (2014) in groundnut.

\section{Mobilization efficiency (\%)}

The mean mobilization efficiency decreased at the initial stage from 9.66 to 7.40 per cent after eight months of storage irrespective of packaging materials and forms. Among the packaging materials significantly higher mobilization efficiency of 8.77 per cent was recorded in the seeds stored in PICS bag, followed by seeds stored in polythene bag $(8.60 \%)$. Whereas, the lowest $(7.51 \%)$ mobilization efficiency was observed in the seeds stored in gunny bag at the end of storage period. The forms also differed significantly on mobilization efficiency during all the months of storage. Mobilization efficiency showed significant difference throughout the storage period the highest $(8.77 \%)$ mobilization efficiency was recorded in seeds stored in the form of pod. Whereas, the lowest $(8.05 \%)$ mobilization was noticed in kernel storage at the end of storage period. Interaction of packaging materials and forms showed non-significant difference throughout the storage period on mobilization efficiency. Mobilization efficiency in seed was mainly attributed to rate of depletion of food reserves with the advancement of storage period. The results obtained in this study showed that natural seed ageing resulted in reduced seedling growth and this is a consequence of decline in weight of mobilized seed reserves (seed reserve depletion). These results are in conformity with the findings of Mohammadi et al., (2011) in soybean.

Based on the above discussion it is clear that from the results obtained, is concluded that irrespective of packaging materials and forms of all the seed quality parameters decreased with the advancement of storage period. In general pod storage showed better seed quality attributes, however, the kernel form stored in impervious containers like PICS bag, polythene bag by reducing its moisture 
content to a desired level also maintained better in seed quality parameters throughout the storage period.

\section{References}

Abdul-Baki, A. A. and Anderson, J. D., 1973, Vigour determination in soybean by multiple criteria. Crop Sci., 13: 630637.

Anonymous, 2011, International Rules for Seed Testing. Seed Sci. and Tech., 21: $1-255$.

Basavegowda and Ravikumar, G. H., 2001, Influence of pod drying techniques and storage containers on seed quality in rabi or summer groundnut. Proc. Nation. Semi Seed Sci. Tech. New Millennium-vistas Vision, Mysore, (India). P. 183.

Doijode, S. D., 1988, Comparison of storage of French bean seeds under ambient conditions. Seed Res., 16:245-247.

Mohammadi, H., Soltanib, A., Sadeghipourc, H. R. and Zeinalib, E., 2011, Effects of seed aging on subsequent seed reserve utilization and seedling growth in soybean. Int. J. Pl. Prod., 5(1): 65-70.

Murdock, L. L., Margam, V., Baoua, I., Balfe, S. and Shade, R. E., 2012, Death by desiccation: effects of hermatic storage on cowpea bruchids. J. Stored Prod. Res., 49: 166-170.

Nautiyal, P.C., Ravindra, V. and Joshi, Y.C., 1990, Varietal and seasonal variation in seed viability in Spanish groundnut. Indian J. Agri. Sci., 60(2): 143-145.

Panse, V. G. and Sukhatme, P. V., 1967, Statistical Methods for Agricultural Workers, ICAR, New Delhi, 167-174.

Patra, A. K., Tripathy, S. K. and Samui, R. C., Panda, P. K. and Nanda, M. K., 1998, Groundnut seed viability as influenced by potassium nutrition (Arachis hypogaea L.). Seed Res., 28(1): 32-35.

Rao, R. G. S., Singh, P. M. and Rai, M., 2006, Storability of onion seeds and effects of packaging and storage conditions on viability and vigour. Scientia Hortic., 110: 1-6.

Shrivastava, A. K. and Sareen, K., 1974, Physiology and biochemistry of deterioration of soybean seeds during storage. Plant Hortic, 7: 545-547.

Sudini. H., Ranga Rao, G. V., Gowda, C. L. L., Chandrika. R., V. Margam and Rathore L. L., 2014, Murdock, Purdue Improved Crop Storage (PICS) bags for safe storage of groundnuts, J. Stored Products Res., 58(1):1-6.

\section{How to cite this article:}

Vijayalakshmi, N. and Malabasari, T.A. 2018. Effect of Packaging Materials and Form Son Storability of Summer Groundnut (Arachis hypogaea L.) Cv. G2-52. Int.J.Curr.Microbiol.App.Sci. 7(11): 760-766. doi: https://doi.org/10.20546/ijcmas.2018.711.091 